\title{
О.В. Бочкарьова
}

\section{ТАКСОНОМІЧНИЙ СКЛАД МІКРОБІОТИ ВМІСТУ ПОРОЖНИНИ ПІХВИ ДІВЧАТ ПУБЕРТАТНОГО ВІКУ}

Хмельницький обласний госпіталь ветеранів війни

Резюме. У роботі проведено аналіз мікробіологічного обстеження вагінального секрету 162 дівчаток пубертатного періоду, хворих на вульвовагініти, 3 метою розкриття механізмів контамінації і колонізації вагінального біотопу мікроорганізмами, що дозволило здійснити аналіз співіснування представників екосисте- ми «макроорганізм (хазяїн) - мікробіота» і прослідкувати динаміку спрямованості змін мікроекології порожнини вагіни при дестабілізації мікробіоценозу.

Ключові слова: вульвовагініт, дівчата пубертатного періоду.

ху інвазії мікроорганізмів є слизові оболонки, як невід'ємна складова частина спадкового імунітету людини. Епітеліальні клітини слизової оболонки здатні до ініціації факторів адаптивного імунітету, патологічних процесів, а також до формування толерантності щодо коменсальних мікроорганізмів зі складу мікрофлори [7].

Мета дослідження. Дослідити особливості мікробіоценозу вульви та піхви в дівчат із вульвовагінітами.

Матеріал і методи. Нами проведені мікробіологічні обстеження вагінального секрету 3 метою вивчення таксономічного складу мікробіоти вагінального вмісту в 162 дівчаток пубертатного періоду, хворих на вульвовагініти.

Для розкриття механізмів контамінації і колонізації вагінального біотопу мікроорганізмами (бактеріями, грибами, мікоплазмами, уреаплазмами, хламідіями та вірусами) використаний мікроекологічний метод, який дозволив здійснити характеристику співіснування представників екосистеми «макроорганізм (хазяїн) - мікробіота» i прослідкувати динаміку спрямованості змін мікроекології порожнини вагіни при дестабілізації мікробіоценозу.

Результати дослідження та їх обговорення. Мікробіологічні дослідження показали, що домінуючих мікроорганізмів (індекс постійності більше 50\%) у вагінальному вмісті дівчаток пубертатного періоду не виявлено. Додаткова мікробіота вмісту порожнини вагіни представлена гарднерелами (Gardnerella vaginalis), фекальними ентерококами, кишковими паличками. Близькими до цих мікроорганізмів за індексом постійності, частотою зустрічальності, індексами видового домінування Сімпсона, Бергера-Паркера є дріжджоподібні гриби роду Candida (індекс постійності $24,69 \%$ ), частота зустрічальності 0,13$)$, уреаплазми (індекс постійності 24,07 \%).

До випадкових мікроорганізмів, що виявляються у вагінальному вмісті дівчаток пубертатного віку, хворих на вульвовагініти, належать хламідії, гемолітичний стафілокок, $\alpha$-гемолітичний стрептокок, протей, Klebsiella oxytoca, ентеробактерії та інші мікроорганізми.

Важливіше 3 нашої точки зору, виявлення у вагінальному вмісті дівчаток пубертатного віку, 
Таксони мікробіоти вагінального вмісту дівчаток пубертатного періоду, хворих на вульвовагініти, що виявляються у монокультурі

\begin{tabular}{|c|c|c|}
\hline Монокультура & Абс. & $\begin{array}{c}\text { Індекс постійності } \\
(\%)\end{array}$ \\
\hline Gardnerella vaginalis & 18 & 11,11 \\
\hline Enterococcus faecalis & 8 & 4,94 \\
\hline Ureaplasma urealyticum & 8 & 4,94 \\
\hline Escherichia coli & 7 & 4,32 \\
\hline Candida albicans & 3 & 1,85 \\
\hline Mycoplasma hominis & 2 & 1,23 \\
\hline Papilloma virus type 16 & 1 & 0,62 \\
\hline Papilloma virus type 18 & 1 & 0,62 \\
\hline Candida krusei & 1 & 0,62 \\
\hline Streptococcus pyogenes & 1 & 0,62 \\
\hline Trichomonas vaginalis & 1 & 0,62 \\
\hline
\end{tabular}

хворих на вульвовагініти, внутрішньоклітинних мікроорганізмів (уреаплазм, мікоплазм, вірусів папіломи людини типу 16 і 18) у 39,51 \% пацієнток. Персистенція внутрішньоклітинних мікробів завжди призводить до формування вторинного як локального, так і системного імунодефіцитного стану.

Розвиток локального, особливо, і системного імуодефіцитного стану організму дівчат пубертатного віку, хворих на вульвовагініт, сприяє росту та розмноженню в біотопі дріжджоподібних грибів роду Candida - розвивається мікозний (кандидомікозний, кандидозний) вульвавагініт. Серед обстежених дівчаток пубертатного віку, хворих на вульвовагініт, у 40 (24,69 \%) верифікований кандидомікозний вульвовагініт, у 39 (24,7 \%) хворих вульвовагініт був зумовлений Candida albicans, в однієї дівчинки - Candida krusei.

Таким чином, вульвовагініт у дівчаток пубертатного віку зумовлюють Gardnerella vaginalis (у 38,27\%), Enterococcus faecalis (у 31,48 \% випадків), Escherichia coli та інші ентеробактерії (у 33,34 \%), мікроорганізмами 3 внутрішньоклітинним типом паразитизму - уреаплазми, хламідії, мікоплазми, віруси папіломи людини типів $16 \mathrm{i}$ 18 виявлені у 64 (39,51\%). Небезпечним є факт персистенції вірусів папіломи 16 і 18 типів, які належать до високоанехогенних вірусів та асоціюються з раком шийки матки.

Мікробіологічне та імунологічне обстеження (встановлення зростання титру антитіл щодо вірусів папіломи людини, уреаплазми, мікоплазми, хламідії) показало, що із 162 зразків вагінального вмісту дівчаток пубертатного віку, хворих на вульвовагініт, виділено та ідентифіковано 326 штамів мікроорганізмів. Вказане свідчить про те, що у вмісті порожнини вагіни персистують асоціації різних таксонів, які і формують вульвовагініт та його клінічну маніфестацію.

У більшості (68,52 \%) дівчаток пубертатного віку, хворих на вульвовагініти, у вагінальному вмісті персистують асоціації умовно-патогенних бактерій, хламідії, мікоплазми, уреаплазми, папіломавірусів людини. Найчисельнішою є асоціація, що складається із двох таксонів мікроорганізмів, але у трьохх пацієнтів асоціацію створюють п'ять видів мікроорганізмів, а у двох дівчаток асоціація нараховує шість видів мікроорганізмів.

Найчастішим збудником запального процесу репродуктивних органів дівчаток пубертатного періоду, хворих на вульвовагініт, що виявляється в монокультурі, є гарднерели, які ізольовані 3 вмісту вагіни у 18 (11,11 \%) пацієнток. Приблизно в 5 \% хворих дівчаток пубертатного віку виявляються в монокультурі Enterococcus faecalis або Ureaplasma urealyticum. Дещо рідше у вагінальному вмісті хворих дівчаток виявилися кишкові палички (у 4,32 \%), дріжджоподібні гриби роду Candida (2,47 \%) i Mycoplasma hominis (1,23\%).

Мікроорганізми, що виявлені в монокультуpi, вважаються збудниками вульвовагініту в дівчаток пубертатного періоду. Результати виділення та ідентифікації мікроорганізмів, що персистують у вагінальному вмісті дівчаток пубертатного періоду, хворих на вульвовагініт, наведені в таблиці.

Таким чином запальний процес, що характеризується клінічно як вульвовагініт, визивають у монокультурі бактерії - (Gardnerella vaginalis, Enterococcus faecalis, Escherichia coli та ін.), умовно-патогенні гриби (Candida albicans, Candida krusei) та внутрішньоклітинні ультрапаразити (Ureaplasma urealyticum, Mycoplasma hominis, Papilloma virus). Це $є$ свідченням про те, що вульвовагініт у дівчаток пубертатного періоду розвивається і проходить під впливом персистенції у вагінальному вмісті в монокультурі мікроорганізмів, що належать до 11 різних таксономічних груп бактерій, мікоплазм, уреаплазм, вірусів та дріжджоподібних грибів роду Candida. Це підтверджує концепцію про те, що вульвовагініти - це інфекційний процес поліетіологічної структури.

Як було сказано вище, із вагінального вмісту 162 дівчаток пубертатного періоду, хворих на 
вульвовагініти, виділено та ідентифіковано 326 мікроорганізмів, які належать до 21 різного таксона. Це є свідченням того, що крім монокультури збудників вагініту в запальному процесі беруть участь асоціації.

Iз 26 асоціацій умовно-патогенних мікроорганізмів, ізольованих із вульвовагінального вмісту дівчат пубертатного періоду, хворих на вульвовагініт, найчисельнішою була асоціація, що складалася із Gardnerella vaginalis i Staphylococcus epidermidis (8,02\%); Gardnerella vaginalis i Enterococcus faecalis (4,32 \%); Gardnerella vaginalis i Candida albicans (2,47\%); Gardnerella vaginalis i Ureaplasma urealyticum $(1,23 \%)$. Чacтими були асоціації Candida albicans i Enterococcus faecalis $(2,47 \%)$; Candida albicans $i$ Escherichia coli (2,47\%); Candida albicans i Staphylococcus epidermidis (2,47\%); Candida albicans i Trichomonas vaginalis $(1,23 \%)$; Candida albicans i Klebsiella pneumoniae (0,62\%); а також асоціації, що складаються із Enterococcus faecalis i Escherichia coli (4,94\%); Enterococcus faecalis та Ureaplasma urealyticum $(1,85 \%)$; Enterococcus faecalis i Trichomonas vaginalis (1,23\%); Ureaplasma urealyticum ma Escherichia coli (1,85 \%); Ureaplasma urealyticum та Mycoplasma hominis (3,09 \%); Ureaplasma urealyticum i вірус папіломи людини $(0,62 \%)$ та інші різні за таксономічним станом асоціації.

У результаті проведених досліджень, направлених на встановлення етіологічної структури вульвовагініту, виявлено всього 47 різних за таксономічною структурою асоціацій. Найбільша кількість асоціацій складалася 3 двох різних таксонів. Їх було 26, що становить 55,32 \% від всіх асоціацій. Найчисельнішою (27,66 \%) була асоціація, що складалася із Gardnerella vaginalis i Staphylococcus epidermidis; Enterococcus faecalis та Escherichia coli - 17,02 \%; Gardnerella vaginalis $i$ Enterococcus faecalis - 14,89\%; Ureaplasma urealyticum i Mycoplasma hominis - 10,64 \%. Всі інші структуровані асоціації траплялися рідше (менше $10 \%)$.

Асоціацій, що складаються із трьох видів мікроорганізмів, виявлено 10. Найчисельнішими були асоціації, що сформовані Candida albicans + Enterococcus faecalis та Escherichia coli $(2,47 \%$ і $8,51 \%$ від усіх асоціацій); Gardnerella vaginalis + Escherichia coli та Ureaplasma urealyticum $(1,85 \%$ i $6,38 \%$ ); Ureaplasma urealyticum + Enterococcus faecalis та Escherichia coli (1,23\% i 4,56 \%). Інші структуровані асоціації, сформовані із трьох таксонів мікроорганізмів, траплялися рідко (2,13\%).

Менше (у 14,89 \%) виявлено асоціацій умовно-патогенних мікроорганізмів, що сформовані 3 чотирьох таксонів. Найчастішими асоціаціями виявлялись асоціації, що складалися із Gardnerella vaginalis, Enterococcus faecalis, Escherichia coli i Trichomonas vaginalis (4,26\%); Gard- nerella vaginalis, Enterococcus faecalis, Escherichia coli i Staphylococcus epidermidis (4,26 \%); Enterrococcus faecalis, Escherichia coli, Ureaplasma urealyticum i Mycoplasma hominis (4,26 \%). Таксономічний склад інших чотирьох асоціацій траплявся тільки один раз.

Асоціації, що складалися з п'яти видів мікроорганізмів, які належать до різних таксономічних груп, виділені у трьох дівчат, хворих на вульвовагініт. Одна, що складається із Gardnerella vaginalis, Candida albicans, Escherichia coli, Ureaplasma urealyticum i Staphylococcus aureus, виявлена у двох пацієнток (4,26 \%). Інша виявлена в однієї дівчинки.

Різні за таксонемічною структурою асоціації, що складаються із шести видів, виявлені у двох дівчаток пубертатного періоду, хворих на вульвовагініт.

\section{Висновок}

Таким чином, вульвовагініт у дівчаток пубертатного періоду є поліетіологічним захворюванням, причиною якого є монокультури (у 31,48 \% пацієнтів) Gardnerella vaginalis, Ureaplasma urealyticum, Enterococcus faecalis, Escherichia coli, Mycoplasma hominis та інші, а в більшості $(68,52 \%)$ випадків є асоціації патогенних та умовно-патогенних мікроорганізмів, які складаються із двох таксонів (26 асоціацій - 55,82 \%), трьох видів (10 асоціацій - 21,28 \%), чотирьох таксонів (сім асоціацій - 14,89\%), п'яти і шестити видів мікроорганізмів (по дві асоціації - 4,26 \%).

Перспективи подальших досліджень. Вдосконалити методи діагностики, оптимізувати лікування та профілактику вульвовагінітів у дівчат для збереження репродуктивного потенціалу в майбутньому.

1. Бенюк О.В. Корекція біотопу піхви у жінок репродуктивного віку 3 генітальним герпесом / О.В. Бенюк, Л.Д. Ластовецька, О.А. Щерба // Репродукт. ендокринол. - 2015. - № 2 (22). - С. 40-44.

2. Адамян Л.В. Инфекционновоспалительные заболевания гениталий у детей и подростков // Акушерство и гинекол. - 2012. - № 4/1. - С. 108-112.

3. Пирогова В.І. Шляхи реалізації сексуальності в сучасних умовах дівчат-підлітків / В.І. Пирогова, О.Р. Цьолко, Е.Ф. Чайківська // Зб. наук. праць асоц. акуш.гінекол. України. - К.: Інтермед, 2011. - С. 672-676.

4. Рутинська Г.В. Роль факторів місцевого імунітету в розвитку вагінального дисбіозу у дівчаток препубертатного та пубертатного віку / Г.В. Рутинська, В.М. Астахов, О.М. Носенко // Репродукт. ендокринол. - 2015. -№ 2 (22). - С. 50-55.

5. Татарчук Т.Ф. Становление репродуктивной функции у девочек с аутоимунным тиреоидитом / Т.Ф. Татарчук, Н.Б. Зелинская, И.В. Бачинская // Укр. ж. дит. ендокринол. - 2013. - № 2. - С. 75-76.

6. Чайківська Е.Ф. Стан репродуктивного здоров'я дівчат львівської області / Чайківська Е.Ф. // Репродукт. ендокринол. - 2015. - № 2 (22). - С. 16. 


\section{ТАКСОНОМИЧЕСКИЙ СОСТАВ МИКРОБИОТЫ ВЛАГАЛИЩА ДЕВУШЕК ПУБЕРТАТНОГО ПЕРИОДА}

\section{О.В. Бочкарева}

Резюме. В работе проведен анализ микробиологических исследований вагинального секрета 162 девушек пубертатного периода, больных вульвовагинитами, с целью раскрытия механизмов контаминации и колонизации вагинального биотопа микроорганизмами, что позволит осуществить анализ сосуществования представителей экосистемы «макроорганизм (хозяин) - микробиота» и отследить динамику изменения микроэкологии влагалища при дестабилизации микробиоценоза.

Ключевые слова: вульвовагинит, девушки пубертатного периода.

\section{TAXONOMIC COMPOSITION OF MICROBIOTA OF THE CONTENTS OF VAGINAL CAVITY IN THE GIRLS OF PUBERTY AGE}

\section{O.V. Bochkariova}

Abstract. The paper conducts analysis of the microbiologic examination of the vaginal secretion in 162 girls of puberty age who suffered vulvovaginitis. The aim of the study was to reveal the mechanisms of contamination and colonisation of vaginal biotope by microorganisms. The characteristics of co-existense of the representavives of the ecosystem "macroorganism (host) - microbiota" have been given in the paper, as well as the dynamics of the changes of the microecology of vaginal cavity in case of destabilisation of microbiocenosis.

Key words: vulvovaginitis, girls of puberty age.

Regional hospital for war veterans (Khmelnytskyi)

Рецензент - проф. С.Є. Дейнека

Buk. Med. Herald. - 2015. - Vol. 19, № 4 (76). - P. 27-30

Надійшла до редакції 28.10.2015 року

(C) О.В. Бочкарьова, 2015 